\title{
RETRACTED ARTICLE: RINT1 is a new suppression target to reduce colon cancer cell growth, migration and invasion through regulating ZW10/NAG-1 expression
}

\author{
Jinheng $\mathrm{Xu}^{1} \cdot$ Meng Zhao ${ }^{1}$. Shunxian Huang ${ }^{2} \cdot \mathrm{Qian} \mathrm{Wu}^{1} \cdot \mathrm{Minghe} \mathrm{Bai}^{1} \cdot$ Xueli Zhao ${ }^{1}$. Jixian Wang ${ }^{1} \cdot$ Yueming Hu$^{1}$. \\ Junwei Feng ${ }^{3} \cdot$ Zhiyong Zhang $^{1}$ (D)
}

Received: 13 April 2020 / Accepted: 24 July 2020 / Published online: 4 August 2020

(C) The Author(s) 2020

The Editor in Chief retracted this article because of significant concerns regarding figures 4 and 8 presented in this work, which question the integrity of the data. All authors agree to this retraction. The online version of this article contains the full text of the retracted article as Supplementary Information.

Supplementary Information The online version contains supplementary material available at https://doi.org/10.1007/s11010-020-03858-9.

Open Access This article is licensed under a Creative Commons Attribution 4.0 International License, which permits use, sharing, adaptation, distribution and reproduction in any medium or format, as long as you give appropriate credit to the original author(s) and the source, provide a link to the Creative Commons licence, and indicate if changes were made. The images or other third party material in this article are included in the article's Creative Commons licence, unless indicated otherwise in a credit line to the material. If material is not included in the article's Creative Commons licence and your intended use is not permitted by statutory regulation or exceeds the permitted use, you will need to obtain permission directly from the copyright holder. To view a copy of this licence, visit http://creativecommons.org/licenses/by/4.0/.

Publisher's Note Springer Nature remains neutral with regard to jurisdictional claims in published maps and institutional affiliations.
Zhiyong Zhang

zhiyongzhang23@163.com

1 Department of Pathology, Tangshan Gongren Hospital, Lubei District, No. 27 Wenhua Road, Tangshan 063000, Hebei, China

2 Department of Biological Science, College of Life and Environmental Sciences, Minzu University of China, Beijing 100081, China

3 Department of Oncological Surgery, Tangshan Gongren Hospital, Lubei District, No. 27 Wenhua Road,

Tangshan 063000, Hebei, China 